\title{
CRITICAL REVIEW ABOUT THE DIFFERENCES OF THE LINGUISTIC MOOD BETWEEN ARABIC AND ENGLISH LANGUAGES
}

DHUHA ABDULJABBAR FATHI,

Muhammed Fauzi Juminganc, Muhd Suki Othmand

University Putra Malaysia

\section{Abstract}

This article presents an exhaustive review of these studies and suggests a direction for future developments. This current study shed light on the meaning of mood in Arabic and English Languages. Also, the differences between them and effect of this mood on the linguistic an speech act. This papers have been takled the type of mood in Arabic and English languages.

Keywords: Mood; Indicative Mood; Subjunctive Mood; and Imperative Mood.

\section{Council for Innovative Research}

Peer Review Research Publishing System

Journal: Journal of Advances in Linguistics

Vol.5 No 3

editor@cirjal.com

www.cirjal.com, 


\section{Concept of Mood}

Mood is realized by distinction in the form of the verb, usually to express the attitude of the speaker towards what he says. It is the hypothesis is that the seven imperative frames are universal mental representations which are overtly expressed in some languages by the category of aspect ( e.g. , Russian, Polish, Czech, etc. ), signaled by modal particles in others ( e .g. , Danish ,German ,etc. ) ,or expressed by indirect speech acts in some others ( e.g. , English, French , etc. ). Thus in order to realize that English speakers and hearers make use of imperative frames we have to resort to indirect speech acts. Durst-Andersen, 1995 suggests that the reason why English speakers prefer an indirect speech act to a direct one is to be found in the very fact that the imperative is vague with respect to the preconditions laid down and the referee also to the post conditions. When hearing a direct speech act the hearer cannot be sure whether the speaker prescribes or describes the conditions, but when he hears an indirect one, there will be no ambiguities and no vagueness in the specific speech situation. In Danish, the situation is slightly different from the English one. Here the imperative form is used more often as a direct speech act, presumably, because the Danish language possesses particles, which will be called "modalizers". These modalizers point to the exact status of the preconditions. Below will be presented various types of evidence in favour of the suggestion that the imperative form itself serves as an index of a frame which consists of three different pieces of content with two different sets of conditions: in Russian we have evidence from the use of aspect in connection with the imperative mood, in Danish we have evidence from the use of modalizers, and in English we have evidence from the use of indirect speech acts. These three independent pieces of evidence will be considered in turn ( Durst-Andersen, 1995).

\section{Mood in Arabic}

Mood or "mode" refers to the Arabic verb properties indicative, subjunctive, jussive, imperative and emphatic. These categories reflect or are caused by contextual modalities that condition the action of the verb. For example, the indicative mood tends to be characteristic of straightforward, factual statements or questions, while the subjunctive mood reflects an attitude toward the action such as doubt, desire, intent, wishing, or necessity, and the jussive mood, when used for the imperative, indicates an attitude of command, request, or need for action on the part of the speaker( Wright 1967).

In Arabic, mood marking is only done on the present tense or imperfective stem; there are no mood variants for the past tense. The Arabic moods are therefore non-finite; that is, they do not refer to points in time and are not differentiated by tense. Tense is inferred from context and other parts of the clause (Karin).

\section{Types of Mood in Arabic}

The Arabic verb has five moods: the indicative (الرفع) the subjunctive (النصب), the jussive (الجزم) (الجر) , the imperative and the emphatic (التوكيد) (Aziz, 1989:82).

These are expressed by means of verb form contrasts.

\section{The Indicative Mood: حالة الرفع}

The indicative mood is considered the basic mood; it is used in factual statements or straightforward questions. It is also used in statements about the future, either with the future markers sa- w w w or sawfa in a context that refers to a future action. This mood is common to both the imperfect and the perfect forms. In the imperfect it has $g(-u=(d h a m m a)$ at its end); in the perfect it is expressed by $(-\mathrm{a}=($ fatha $))$. The indicative mood is the unmarked mood.

\section{The Subjunctive Mood: حالة النصب}

Is confined to the imperfect. It is used in the subordinate clauses and follows certain particles (النواصيب) which are said to govern the verb in the subjunctive. (The only exception of the subjunctive occurring in the main clauses is that of (لن). The particles governing the verb in the subjunctive mood are:

a- لن : لن :negation for the future (will not)

Ali will not attend the class.

b- أن : in complementation of certain verbs.

I want to play with you.

c- كي,لكي, ل : so that, in order that, that. These particles express intention, purpose, etc.

جائت الثرطة لتلقي القبض على اللص (The police came to arrest the thief.)

ينبغي أن تصغي كي تعرف الجواب (You must listen so that you should know the answer.)

d- : till , until, in order that (this particle expresses time or purpose.

) لابد ان يسجن اللص حتى يتوب (The thief must be imprisoned so repent.)

that he should

e- $\quad$ e : فاء السبيية This particle expresses cause, and is known as is similar to حتى in this sense.

(Don't say that lest you should be sorry) 
There are certain restrictions on the use of this particle: it is only used where the main close is imperative (positive or negative), interrogative, or merely a negative one. It may also express a wish or a hope.

لماذا لاتقول شيئا من الثعر فنأنس في هذه الجلسة. (Why don't you recite some poetry so that we may enjoy this session)

f- $\quad$ g This particle is subject to the same constraints as $\mathbf{i}$, It has an additive sense (Don't preach against what yourself practice.)

g- أو (unless that, until). لا تستهلن الصعب أو أدرك المنى. (I'll consider all difficult things easy until I attain my aim.)

h- اذن (in that ease, well then). This particle expresses a result or consequence and governs the verb in the subjunctive if it follows immediately.

سأدفع للك الثمن اليوم-اذن أرسل للك البضاعة في الحال.

(I'll pay you today. Well then, I'll send the goods at once.)

\section{The Jussive Mood: حالة الجزم}

like the subjunctive mood, is used with the imperfect verb only. Its main uses are: (1) after certain particles الجوازم in clauses with imperative signification and (3) in conditional sentences. The forms of the jussive are basically the same as those of the subjunctive except that where the subjunctive has 'fatha' I, the jussive has 'sukun' ${ }^{\text {. }}$ (Aziz, 1989:82).

\section{The Emphatic Mood: حالة التوكبي}

The Energetic of the imperfect is used:

a- with particle (ل) لام truly, verily, surely, prefixed to it, both in simple asseverations and in those that are strengthened and oath, as

$$
\text { "و الذين جاهدو فينا لنهديهم سبلنا" }
$$

b- In commends or prohibitions wishes and questions, as "فلاتموتن ألا و أنتم مسلمون"

c- In the apodosis of correlative conditional clauses, in which case $J$ is prefixed to the protasis as well as to the الئن لم ينته لنسفعا بالناصية

d- In the protasis of a sentence after اما as; "هيطو منها جميعا فأما ياتينكم مني هدى فمن تبعى هداي فلا خوف عليهم"

\section{The Imperative Mood: حالة الأمر}

The imperative or command form of the verb in Arabic is based upon the imperfect/ present tense verb in the jussive mood. It occurs in the second person (all forms of "you"), for the most part, although it occasionally occurs in the first person plural ("let's") and the third person ("let him/her/them").

The general rule for forming the imperative is to take the second person form of the jussive verb and remove the subject marker (the ta- or tu-prefix). If the remaining verb stem starts with a consonant-vowel sequence, then the stem is left as it is because it is easily pronounceable. If the remaining stem starts with a consonant cluster, then it needs a helping vowel prefix. The nature of the helping vowel depends on the verb form and the nature of the stem vowel.

For example, the verb katab-a 'to write' in the present tense, jussive mood, second person is:

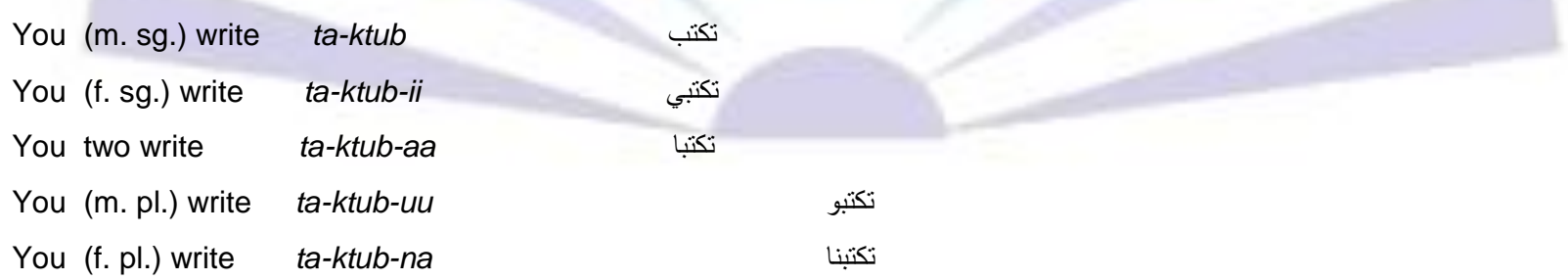

To create the imperative, the ta- prefix is dropped, leaving:

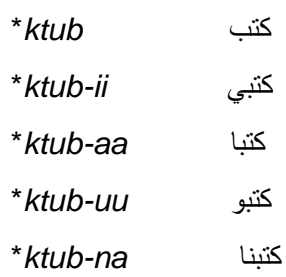

Because these forms start with consonant clusters, they violate a phonological rule in Arabic that prohibits word-initial consonant clusters. They therefore need a helping vowel to be pronounceable. The helping vowel selected in this case is $/ \mathrm{u} /$ because the stem vowel of the verb is / $u /$. However, another rule in Arabic prohibits words from starting with vowels, so 
the / $u /$ vowel is preceded by hamza, and the hamza plus short vowel sit on an Valif seat. This yields the pronounceable forms:

Write!

$\begin{array}{cc}\text { u-ktub! } & \text { أكتب! } \\ \text { u-ktub-ii! } & \text { أكتبب! } \\ \text { u-ktub-a! } & \text { أكبن!! } \\ \text { u-ktub-u! } & \text { u-ktub-na! }\end{array}$

This helping vowel is used with hamzat al-wasl, that is, elidable hamza, which is normally not written and drops out if it is preceded by another vowel, as in:

Read and write! i-qraل wa-ktub! أو أكتب أبn

\section{Mood in English:}

Jespersen's study of different moods (1924) serves as a good starting point to our discussion. He is a representative of the traditional view, stating that the indicative, the subjunctive and the imperative "express certain attitudes of the mind of the speaker towards the contents of the sentence, though in some cases the choice of a mood is determined not by the attitude of the actual speaker, but by the character of the clause itself and its relation to the main nexus on which it is dependent. Further it is very important to remember that we speak of 'mood' only if this attitude of mind is shown in the form of the verb: mood thus is a syntactic, not a notional category". (Jespersen 1924: 313).

Charleston (1941) is a study of the verb in early $18^{\text {th }}$ century English and of the grammatical description of that period. It's very last sentence, quoted with approval by Michael (1970: 434), says that "the treatments of moods by these grammarians of the $17^{\text {th }}$ and $18^{\text {th }}$ century shows a confusion and hesitancy which is still to be observed to-day among modern grammarians". If one extends the perspective to the entire tradition of the grammarians' uses of mood concepts, from Antiquity to the modern age, and further extends it to include modality concepts, the impression is the same. There have been thousands of grammatical discussions of mood and modality and though some linguists are self-assured and clear, the field as a whole cannot be said to have come to grips with these notions. This avowal has a negative and a positive side. The negative side is obvious: it is sad that after more than 2000 years our discipline has not reached a better understanding of what is fundamental to mood and modality. On the positive side, one gets the feeling that the subject matter of mood and modality is a fascinatingly difficult one and also that one can still learn from past scholarship.

According to Palmer $(1986,21)$, "the term 'mood' is traditionally restricted to a category expressed in verbal morphology. It is formally a morphosyntactic category of the verb like tense and aspect. According to Palmer (1986, 16), incorporates the notion of subjectivity, i.e.. the attitudes and opinions of the speaker with respect to the given utterance. Mood, then, might be defined as "the grammaticalization of speakers' (subjective) attitudes and opinions" (Palmer 1986, 16).

\section{Types of Mood in English}

Linguistically, English has the indicative, subjunctive, imperative moods; others, such as the conditional, do not appear as morphologically distinct forms.

\section{Indicative Mood}

According to The Cambridge History of the English Language. Richard M. Hogg, Roger Lass, Norman Francis Blake, Suzanne Romaine, R. W. Burchfield, John Algeo (2000). Indicative mood is a grammatical mood which is used principally to indicate that something is actually the case (or actually not the case) - in other words, to express what the speaker considers to be a known state of affairs, as in declarative sentences. Most languages have a single indicative mood called the realis mood, although some languages have additional realis moods, for example to express different levels of certainty.

In the following sentences the speaker is merely stating something; the indicative mood of the verb is used.

- He comes here everyday.

- She did not pay the bill.

- Susan sings beautifull.

- The weather is cold.

\section{Subjunctive Mood}

Quirk et al. (1985: 1012-1013) define the subjunctive occurring "in that-clauses after verbs, adjectives, or nouns that express a necessity, plan, or intention for the future" as the mandative subjunctive and this is this use of the subjunctive that "[this] corpus-based investigation of language change in progress" is focusing on.

Johansson and Norheim (1988: 27) state nonetheless and without any doubt that "English verbs have distinctive forms under certain circumstances which differ from the normal indicative forms and convey the meaning of 'non-fact', which is characteristic of the subjunctive in other languages". 
Givón (1994) claims that the subjunctive in complement clauses is closely related to the irrealis modality, more specifically it occupies two coherent regions along the two sub-dimensions of irrealis, these being:

- within the epistemic sub-dimension: the subjunctive of lower certainty

- within the deontic sub-dimension: the subjunctive of weaker

manipulation. (Givón 1994: 278)

\section{Imperative Mood}

Jespersen (1964:248), for example ,defines the imperative as being a" request". On the other hand, Curme (1931:430) regards the imperative as one of the oldest grammatical categories. He defines the imperative as:

"The mood of command, request, admonition, supplication, entreaty, warning, prohibition. Forms for expression of will are older than those for the expression of actual fact. The simple imperative, as in eat, sit, etc., antedates inflection. It is an old un inflected form, which be longs with interjections, like 0! Ouch ! belongs to the oldest forms of spoken speech. Though the oldest imperative form, it is still widely used, but now it is only one of many forms, for today the expression of one' $s$ will is no longer a simple matter as in the earliest period when men were less differ-entiated and less sensitive ".(1931,p.430)

From the point of view of the ordinary speaker, this procedure of defining the imperative by making an inventory of the uses it might imply, may actually complicate the problem. This is because in ordinary speech some of these terms are seen as being somehow mutually exclusive. AL-Daifallah (1984)

As far as Person is concerned, many grammarians agree that the subject of an imperative must be in the second-person. The most recurring argument, however, for an underlying second-person imperative subject has been derived from tag questions whose pronouns reflect the subject of the preceding statement: I ate the meat, didn't I ? The argument goes like this: since tags attached to imperatives have only 'you' e.g. Eat the meat, will you then the underlying subject 'you' must have been deleted.

\section{Conclusion}

a- There are five moods in the Arabic verb system; the English verb system has three moods. This makes the morphology of the Arabic verb more complicated, since these moods are realized by means of form contrasts. Compare:

with, he writes, he write (subjunctive), write (imperative).

The picture is even more complicated if we take into consideration the fact that Arabic verbs vary according to the gender, number, and person. The English verb varies according to the person of the subject (only $3^{\text {rd }}$ person singular) and to the number (singular and plural).

b- Formally the indicative and the imperative moods in the two languages correspond. The indicative, in both languages, is use to state something; the imperative to persuade somebody to do something.

c- The subjunctive and the jussive are basically morphological have no counterparts in English.

d- The energetic mood is used in Arabic to emphasize what is uttered.

This sense is often realized in English by means of modal verbs (among other things); e.g . لاعبنَه : I must punish him; I will certainly punish him.

\section{References}

AL-Daifallah A. S. (1984)IMPERATIVE CONSTRUCTIONS IN CONTEMPORARY ENGLISH (FUNCTIONAL). Indiana University, $241 \mathrm{p}$.

Aziz, Y. A. (1989). A Contrastive Grammar of English and Arabic. Mosul: Mosul University Press.

Bell, R. T. (1991). Translation and Translating Theory and Practice.London: Longman Group Ltd.

Ben Ayed, Hela.(2003) Mood and functional projections, McGill University. Canada.

Bolinger, Dwight (1967), "Imperatives in English", in To Honor Roman Jacobson, The Hague: Mouton, 335 - 362.

(1974), "Do Imperative" Journal of English Linguistics 8,1-5.

Bybee, Joan; Perkins, Revere; and Pagliuca, William. The Evolution of Grammar, Univ. of Chicago Press, 1994.

Chafe, Wallace (1976), "Givenness, Contrastiveness, Definiteness, Subjects, Topics, and Point of View",in C.Li,ed. Subject and Topic, New York: Academic Press, 25-56.

Chomsky, Noam (1975), The Logical Structure of Linguistic Theory, New York : Plenum Press, 553-54.

Curme, George (1931), Syntax, Boston : D.C . Heath and Company. 
Durst-Andersen, Per.( 1995). Imperative frames and modality: Direct vs. indirect speech acts in Russian, Danish, and English. Linguistics and Philosophy, 18(6), 611-653.

Daniel B. Wallace,(1996), Greek Grammar beyond the Basics: An Exegetical Syntax of the New Testament (Grand Rapids: Zondervan Publishing House), 485-93.

Givón, T. (1994). "Irrealis and the Subjunctive". Studies in Language 18:2, 265-337.

Katz, Jerrold, and Paul Postal (1964), An Integrated Theory of Linguistic Descriptions, Cambridqe: MIT Press.

Keenan, Edward (1976), "Towards a Universal Definition of 'Subject", in C. Li , ed. ,Subject and Topic, New York : Academic Press, 303 - 333.

Klima, Edward (1964), "Negation in English", in Jerry A. Fodor and Jerrold J. Katz, eds . , ^ he Structure of Language, Englewood Cliffs, N. J.: Prentice - Hall, $246-323$.

K. L. McKay, (1985), "Aspect in Imperatival Constructions in New Testament Greek," Novum Testamentum 27, $201-2$.

Lees, Robert (1964), "On Passives and Imperatives", Gengo Kenkyu 46, 28 - 41.

Levenston, E. A. (1969),"Imperative Structures in English", Linguistics 50, 38 - 43.

Li, Charles , and Sandra Thompson (1976 ), " Subject and Topic: A New Typology of Language ", in C. Li, ed. , Subject and Topic, New York: Academic Press, 457 - 490.

Lyons, J. (1977). Statements, questions and commands. In A. Zampolli (Ed.), Linguistic Structures Processing (255-180). Amsterdam: North-Holland.

Millward, Celia M . (1971), Imperative Constructions in Old English, The Hague: Mouton.

Otto Jespersen(1929):The philosophy of Grammar. London: Allen \&Unwin.

Palmer, F. R. (2001). Mood and modality. Cambridge: Cambridge University Press.

Portner, Paul.( 2009). Modality. Oxford: Oxford University Press.

Tóth, Enikő (2008) Mood choice in complement clauses. Frankfurt am Main ; New York:P. Lang, c2008

Wickens, G. M. (1980), Arabic Grammar, London: Cambridge University Press.

Wright, Joseph (1979), An Elementary Middle English Grammar, London: Oxford University Press.

Wright, William (1967), A Grammar of the Arabic Language, Vol. 2, London: Cambridge University Press. 